\title{
Cooling and Warming Effects on Cold Hardiness Estimations of Three Woody Ornamental Taxa
}

\author{
C.L. Haynes and O.M. Lindstrom \\ Department of Horticulture, Georgia Station, Griffin, GA 30223
}

\author{
M.A. Dirr \\ Department of Horticulture, University of Georgia, Athens, GA 30602 \\ Additional index words. Lagerstroemia indica, x Cupressocyparis leylandii, Photinia \\ $\times$ fraseri, lowest survival temperature, frost tolerance, cold resistance
}

\begin{abstract}
Cooling treatments of 2, 4, and 6C/hour or warming at 25, 4, or 0C influenced the cold hardiness estimates of $\mathrm{x}$ Cupressocyparis leylandii (A.B. Jacks. and Dallim.) Dallim. and A.B. Jacks. (Leyland cypress), Lagerstroemia indica L. (crape myrtle), and Photinia $\times$ fraseri Dress 'Birmingham' (redtip photinia) at four times during the year. New growth from all taxa, especially spring growth, was injured or killed at higher temperatures by the fastest cooling rate and/or by warming at $25 \mathrm{C}$. Cold hardiness of Leyland cypress was unaffected by the cooling and warming treatments. Crape myrtle had a significantly higher lowest survival temperature (LST) when warmed at $25 \mathrm{C}$ than at 4 or $0 \mathrm{C}$. Photinia leaves and stems cooled at $6 \mathrm{C} / \mathrm{hour}$ or warmed at $25 \mathrm{C}$ generally resulted in a higher LST than those cooled more slowly or warmed at lower temperatures. Cooling rates of $14 \mathrm{C} / \mathrm{hour}$ and warming at 0 to $4 \mathrm{C}$ should be used in freeze tests with Leyland cypress and crape myrtle. For leaves and stems of photinia, 2C/hour cooling and warming at 0 to $4 \mathrm{C}$ should be used.
\end{abstract}

Rapid cooling rates may increase the degree of freezing injury and/or raise the killing temperature of herbaceous and woody plants (Chandler, 1913; Havis, 1964; Levitt, 1980; Potter, 1924; Slater and Warmund, 1986; Steffen et al., 1989; Warrington and Jackson, 1981; White and Weiser, 1964). Cooling rates of $9.5 \mathrm{C} / \mathrm{min}$ were measured in foliage of Thuja occidentalis L. (American arborvitae), leading White and Weiser (1964) to conclude that the primary cause of winter injury of arborvitae was rapid cooling.

Injury caused by rapid warming occurs less frequently than by rapid cooling (Levitt, 1980). Lumis et al. (1972) reported no differences in warming treatments in midwinter on the survival of leaves of Rhododendron poukhanense Maxim. and Rhododendron $x$ 'Maryann'. Potter (1924) and Havis (1964) concluded that rapid rates of warming, necessary to cause injury, do not normally occur in nature. However, cooling and warming treatments may be more important at different stages of plant development or time of year. Warrington and Jackson (1981) reported, in Pinus radiata D. Don. (Monterey pine), that increasing cooling rate increased the amount of seedling damage in fall and spring tests; while only the highest cooling rate caused significant plant damage in winter.

Quantification of the effects of varying cooling and thawing treatments (Levitt, 1980)

Received for publication 28 Jan. 1992. Accepted for publication 31 July 1992. The cost of publishing this paper was defrayed in part by the payment of page charges. Under postal regulations, this paper therefore must be hereby marked advertisement solely to indicate this fact. during all seasons may be needed to accurately predict the cold hardiness of diverse taxa. Therefore, this study was designed to determine the effects of various cooling and warming treatments on the survival of stem and leaf tissue of a needle evergreen, Leyland cypress; a deciduous flowering shrub, crape myrtle; and a broadleaf evergreen, 'Birmingham' redtip photinia at four times of the year.

Terminal shoots $(7 \mathrm{~cm}$ long) of the three taxa were taken from established plantings in Griffin, Ga. Samples were evaluated for cold hardiness on 7 Oct. 1989 and on 19 Jan., 15 Mar., and 13 Aug. 1990 by cooling them at 2, 4, and 6C/h. On 1 and 23 Mar., 25 July, and 24 Nov. 1990, samples from the same taxa were cooled at $4 \mathrm{C} / \mathrm{h}$ and tested under the following warming conditions: 1 ) room temperature $(25 \pm 2 \mathrm{C})$; 2) refrigeration $(4 \pm 2 \mathrm{C})$; and 3$)$ refrigeration on ice $(0$ $\pm 1 C$ ) after exposure to a freezing treatment. Samples were prepared as described by Dirr and Lindstrom (1990) and Lindstrom and Dirr (1989), with 12 replications per temperature for the cooling experiment and eight for the warming experiment. The samples were nucleated with ice at $-2 \mathrm{C}$ and allowed to equilibrate overnight. The samples were removed at $3 \mathrm{C}$ intervals from -3 to - 30C when thermocouples within the test tubes reached the desired temperature. Samples were evaluated visually (Dirr and LindStrom, 1990; Lindstrom and Dirr, 1989; Stergios and Howell, 1973). Segments showing breakdown of cells and brown discoloration of the cambium and phloem were rated as dead. Nonfrozen controls and noninjured samples remained turgid and green and displayed no brown discoloration. The 
Table 1. Mean lowest survival temperature (LST) $\left({ }^{\circ} \mathrm{C}\right)$ of Lagerstroemia indica tested at various cooling and warming regimes (from Jan. to July 1990).

\begin{tabular}{lccrrr}
\hline & \multicolumn{2}{c}{ Cooling expt. } & & \multicolumn{2}{c}{ Warming expt. } \\
\cline { 2 - 3 } $\begin{array}{l}\text { Cooling rate } \\
\left({ }^{\circ} \mathrm{C} / \mathrm{h}\right)\end{array}$ & LST $\left({ }^{\circ} \mathrm{C}\right)$ & & $\begin{array}{c}\text { Warming } \\
\text { temp }\left({ }^{\circ} \mathrm{C}\right)\end{array}$ & $\frac{\text { LST }\left({ }^{\circ} \mathrm{C}\right)}{25 \mathrm{July}}$ \\
\hline 2 & $-15.8 \mathrm{c}^{2}$ & $-11.0 \mathrm{~b}$ & & 25 & $0 \mathrm{a}$ \\
4 & $-14.5 \mathrm{~b}$ & $-11.0 \mathrm{~b}$ & & 0 & $-2.3 \mathrm{~b}$ \\
6 & $-12.8 \mathrm{a}$ & $-8.5 \mathrm{a}$ & & 0 & $-1.9 \mathrm{~b}$ \\
\hline
\end{tabular}

${ }^{\mathrm{z}}$ Mean separation within columns by Duncan's multiple range test $(P=0.05)$.

number of stems and/or leaves (if present) killed at each temperature was determined and recorded as the lowest survival temperature (LST). The LST was the lowest temperature at which $>50 \%$ of stems from each treatment survived (Sakai et al., 1986). Data were reported as the mean LST. Data were subjected to analysis of variance and means separated by Duncan's multiple range test ( $P$ $=0.05)$.

Leyland cypress. The cooling and warming treatments produced the same estimate or LST of cold hardiness on each sample date (data not presented). However, tip damage (browning) was observed in spring at $6 \mathrm{C} / \mathrm{h}$ cooling, but not on samples cooled at 2 or 4C/h.

Crape myrtle. Cooling at $6 \mathrm{C} / \mathrm{h}$ significantly raised the LST on 19 Jan. and 15 Mar. compared with slower cooling (Table 1). Warming at $25 \mathrm{C}$ also significantly raised the LST on 25 July compared with slower warming. No significant differences from cooling or warming treatments were observed at other dates (data not presented).

Photinia. On 7 Oct. and 19 Jan., cooling of leaves at $4 \mathrm{C} / \mathrm{h}$ resulted in a higher LST than cooling at $2 \mathrm{C} / \mathrm{h}$ (Table 2). On $19 \mathrm{Jan}$. and 15 Mar., cooling at $6 \mathrm{C} / \mathrm{h}$ produced a higher LST than cooling at $2 \mathrm{C} / \mathrm{h}$. Warming at $0 \mathrm{C}$ also gave a higher LST on 25 July than warming at $4 \mathrm{C}$. Warming at $25 \mathrm{C}$ resulted in a higher LST than warming at $4 \mathrm{C}$ on 24 Mar. and 24 Nov. compared with $4 \mathrm{C}$.

Cooling of stems at $6 \mathrm{C} / \mathrm{h}$ significantly raised the LST compared to cooling at $2 \mathrm{C} / \mathrm{h}$ on 19 Jan., 15 Mar., and 13 Aug. (Table 2). Warming at 25C on 24 Mar. 1990, after new growth was initiated, significantly raised the LST compared with slower warming at 0 or 4C. However, on 24 Nov. 1990, warming at $0 \mathrm{C}$ resulted in a significantly lower LST than warming at 25 or $4 \mathrm{C}$.

Conducting preliminary studies to determine the resistance of organs/tissues at various cooling and warming treatments is critical for the most accurate cold hardiness estimations (Levitt, 1980; Mazur, 1963; Steffen et al., 1989). These studies show that the effects of rate and/or temperature of cooling and warming on cold hardiness estimations are most manifest during fall and spring, when stems and leaves differ physiologically from more dormant tissues. However, we agree with Warrington and Jackson (1981) that various cooling and warming treatments may not alter the rankings of taxa for freeze tolerance if rapid rates are avoided. Some preliminary screening under various cooling and/ or warming treatments may be necessary to select a regime suitable to the environment in question and to maximize differences among taxa.

Our results suggest that cooling rates of $\leq 4 \mathrm{C} / \mathrm{h}$ and warming at 0 to $4 \mathrm{C}$ should be used in freeze tests with Leyland cypress and crape myrtle. For leaves and stems of photinia, cooling at $2 \mathrm{C} / \mathrm{h}$ and warming at 0 to 4C should be used in freeze tests.

\section{Literature Cited}

Chandler, W.H. 1913. The killing of plant tissue by low temperature. Univ. of Missouri, Columbia, Agr. Expt. Sta. Res. Bul. 8.

Dirr, M.A. and G.M. Lindstrom. 1990. Cold hardiness of 17 broadleaf evergreen taxa. J. Environ. Hort. 8:71-73.

Havis, J.R. 1964. Freezing Rhododendron leaves. Proc. Amer. Soc. Hort. Sci. 84:570-574.

Levitt, J. 1980. Responses of plants to environmental stresses. vol. I. Chilling, freezing, and high temperature stresses. Academic, New York. p. 101-107.

Lindstrom, O.M. and M.A. Dirr. 1989. Acclimation and low temperature tolerance of eight woody taxa. HortScience 24:818-820.

Lumis, G.P., R.A. Mechlenburg, and K.C. Sink. 1972. Factors influencing winter hardiness of flower buds and stems of evergreen azaleas. J. Amer. Soc. Hort. Sci. 97:124-127.

Mazur, P. 1963. Kinetics of water loss from cells at subzero temperatures and likelihood of intracellular freezing. J. General Physiol. 47:347369.

Potter, G.F. 1924. Experiments on resistance of apple roots to low temperatures. Univ. of New Hampshire Agr. Expt. Sta. Tech. Bul. 27., Durham, N.H.

Sakai, A., L. Fuchigami, and C.J. Weiser. 1986. Cold hardiness in the genus Rhododendron. J. Amer. Soc. Hort. Sci. 111:273-280.

Slater, J. and M. Warmund. 1986. Effect of cooling rate and preacclimation on phloem supercooling in Vitis. HortScience 21:698. (Abstr.)

Steffen, K.L., R. Arora, and J.P. Palta. 1989. Relative sensitivity of photosynthesis and respiration to freeze-thaw stress in herbaceous species. Plant Physiol. 89:1372-1379.

Stergios, B.G. and G.S. Howell, Jr. 1973. Evaluation of viability tests for cold stressed plants. J. Amer. Soc. Hort. Sci. 98:325-330.

Warrington, I.J. and A.K.H. Jackson. 1981. Injury to radiata pine as influenced by freezing and thawing rate, and low temperature duration. N.Z. J. For. Sci. 11:37-44.

White, W.C. and C.J. Weiser. 1964. The relation of tissue desiccation, extreme cold and rapid temperature fluctuations to winter injury of American arborvitae. Proc. Amer. Soc. Hort. Sci. 85:554-563.

Table 2. Mean lowest survival temperature (LST) $\left({ }^{\circ} \mathrm{C}\right)$ of leaves and stems of Photinia $\times$ fraseri tested at various cooling and warming regimes from Oct. 1989 to Nov. 1990.

\begin{tabular}{|c|c|c|c|c|c|c|c|c|}
\hline \multirow[b]{3}{*}{ Conditions } & \multicolumn{8}{|c|}{ Cooling expt. LST $\left({ }^{\circ} \mathrm{C}\right)$} \\
\hline & \multicolumn{2}{|c|}{7 Oct. 1989} & \multicolumn{2}{|c|}{19 Jan. 1990} & \multicolumn{2}{|c|}{15 Mar. 1990} & \multicolumn{2}{|c|}{13 Aug. 1990} \\
\hline & Leaf & Stem & Leaf & Stem & Leaf & Stem & Leaf & Stem \\
\hline $\begin{array}{l}\text { Rate of cooling }\left({ }^{\circ} \mathrm{C} / \mathrm{h}\right) \\
2 \\
4 \\
6\end{array}$ & $\begin{array}{c}-11.3 \mathrm{a}^{2} \\
-9.0 \mathrm{~b} \\
\ldots .\end{array}$ & $\begin{array}{l}-3.0 \mathrm{a} \\
-3.0 \mathrm{a} \\
\ldots .\end{array}$ & $\begin{array}{l}-17.3 b \\
-14.5 \mathrm{a} \\
-15.5 \mathrm{a}\end{array}$ & $\begin{array}{l}-15.3 b \\
-15.0 b \\
-12.8 a\end{array}$ & $\begin{array}{r}-11.8 \mathrm{~b} \\
-11.3 \mathrm{~b} \\
-8.5 \mathrm{a}\end{array}$ & $\begin{array}{l}-12.8 \mathrm{~b} \\
-11.5 \mathrm{ab} \\
-10.9 \mathrm{a}\end{array}$ & $\begin{array}{l}-7.5 \mathrm{a} \\
-7.5 \mathrm{a} \\
-7.1 \mathrm{a}\end{array}$ & $\begin{array}{l}-5.0 b \\
-5.0 b \\
-3.5 \mathrm{a}\end{array}$ \\
\hline & \multicolumn{8}{|c|}{ Warming expt. LST $\left({ }^{\circ} \mathrm{C}\right)$} \\
\hline & \multicolumn{2}{|c|}{1 Mar. 1990} & \multicolumn{2}{|c|}{23 Mar. 1990} & \multicolumn{2}{|c|}{25 July 1990} & \multicolumn{2}{|c|}{24 Nov, 1990} \\
\hline $\begin{array}{l}\text { Warming temp }\left({ }^{\circ} \mathrm{C}\right) \\
25 \\
4 \\
0\end{array}$ & $\begin{array}{l}-13.8 \mathrm{a} \\
-14.6 \mathrm{a} \\
-13.7 \mathrm{a}\end{array}$ & $\begin{array}{l}-13.8 \mathrm{a} \\
-14.3 \mathrm{a} \\
-15.0 \mathrm{a}\end{array}$ & $\begin{array}{r}-9.8 \mathrm{a} \\
-12.0 \mathrm{~b} \\
-12.9 \mathrm{~b}\end{array}$ & $\begin{array}{l}-11.6 \mathrm{a} \\
-14.3 \mathrm{~b} \\
-14.1 \mathrm{~b}\end{array}$ & $\begin{array}{c}-6.0 \mathrm{ab} \\
-6.4 \mathrm{~b} \\
5.1 \mathrm{a}\end{array}$ & $\begin{array}{l}-3.4 \mathrm{a} \\
-4.1 \mathrm{a} \\
-4.3 \mathrm{a}\end{array}$ & $\begin{array}{l}-13.5 \mathrm{a} \\
-15.0 \mathrm{~b} \\
-15.4 \mathrm{~b}\end{array}$ & $\begin{array}{r}-8.3 \mathrm{a} \\
-10.9 \mathrm{~b} \\
-12.9 \mathrm{c}\end{array}$ \\
\hline
\end{tabular}

${ }^{\mathrm{z}}$ Mean separation within columns within experiments by Duncan's multiple range test $(P=0.05)$ 